The end of the War reduced the demand for the special functions the ASLIB Microfilm Service had been set up to fulfil, and by arrangement with the Royal Society of Medicine, it has become an integral part of the Society's Central Medical Library Bureau (so Nature, January 12, p. 44). It is hoped, nevertheless, to be able to continue to serve non-medical demands for documentary reproduction. Requests for copies from existing master negatives may be sent to the old address of the ASLIB Microfilm Service at the Victoria and Albert Museum, London, S.W.7, until January 31. After that date all orders, including requests for copies of individual references from varied literature, should be addressed to the Association of Special Libraries and Information Bureaux, 52 Bloomsbury Street, London, W.C.1.

\section{Royal Commission for the Exhibition of 1851}

Tre Commissioners for the Exhibition of 1851 have decided to re-commence the awards of senior studentships and overseas scholarships for scientific research. The modified regulations provide for the award of four studentships of $£ 500$ a year each, tenable for two years. Overseas scholarships are worth $£ 350$ a year for two years; ten are being offered distributed as follows : Canada, 3 ; Australia and India, 2 each ; South Africa, New Zealand and Eire, 1 each. The sge limits for senior studentships and for scholarships are thirty and twenty-six respectively. Applications must reach the office of the Commissioners by May 1 (from South Africa, Eire and India), and June 1 (Canada, Australia and New Zealand).

The Secretary of the Royal Commission for the Exhibition of 1851 is preparing a new edition of the Commission's "List of Whole-time Research Awards for Scientific Research, other than Professorships, offered by Public and Private Bodies in Great Britain and Northern Ireland". He would be glad to receive at 1 Lowther Gardens, Exhibition Road, London, S.W.7, for inclusion in the revised list particulars of any new awards (of value not less than $£ 150$ ) created since November 1937 and of any alterations made since that date in the value or conditions of existing awards. The list includes : $(a)$ open awards offered by private and public bodies other than universities or colleges, (b) open awards offered by universities or colleges, (c) awards restricted to candidates from particular localities or institutions. It does not include awards offered by universities and scientific societies exclusively for the benefit of their own members nor scholarships for which British subjects are not eligible. It does contain, however, some of the more important fellowships which are available for British subjects although administered by foreign foundations.

\section{Conference on Industry and Research}

A TWO-DAY "Conference on Industry and Research", under the auspices of the Federation of British Industries, will be held at the Kingsway Hall, London, on March 27 and 28. The Conference will take as its leading subject the application of science by industry and the part that research is playing, and can play, in promoting industrial efficiency, exports, full employment and a higher standard of living. It will be divided into four sessions as follows : (1) Science, industry and the community (speakers, Sir William Larke, Sir Edward Appleton, Sir Harold Hartley and Sir Ernest Simon); (2) scientific research and production (speakers, Dr. J. R. Hosking (Paints Div., I.C.I., Ltd.), Mr. A. Healey (Dunlop and Co., Ltd.);
Dr. C. C. Paterson (General Electric Co., Ltd.)) ; (3) scientific research and industrial expansion (speakers, Dr. R. E. Slade (lately research controller, I.C.I., Ltd.), Mr. C. H. Davy (Babcock and Wilcox, Ltd.), Mr. A. J. Philpot (British Scientific Instrument Research Association)) ; (4) application of research in industry (speakers, Dr. P. Dunsheath (Henley's, W. T. Telegraph Works, Ltd.) and Sir Raymond Streat (chairman of the Cotton Board)). Parts of sessions 2, 3 and 4 will be open to discussion; Sir William Larke will sum up at the end of the Conference.

\section{The Night Sky in February}

NEw moon occurs on Feb. 2d. 04h. 43m., U.T., and full moon on Feb. 16d. 04h. $28 \mathrm{~m}$. The following conjunctions with the moon take place: Feb. 13d. 03h., Mars $3^{\circ}$ N.; Feb. 13d. 09h., Saturn $2^{\circ}$ S. ; Feb. 20d. 20h., Jupiter $3^{\circ} \mathrm{S}$. Occultations of stars not fainter than magnitude 6 are as follows : Feb. 9d. 20h. $33 \cdot 2 \mathrm{~m}$., 148 B. Taur. $(D)$; Feb. 12d. 19h. $03 \cdot 3 \mathrm{~m} ., 87$ B. Gemi. $(D)$; Feb. 23d. 03h. 07.0m., 34 Libr. $(R)$; Feb. 23d. 04h. $36 \cdot 5 \mathrm{~m}$., $\zeta$ Libr. $(R)$. The times are for Greenwich, and $(D)$ and $(R)$ refer to disappearance and reappearance respectively. Mercury, in superior conjunction with the sun on Feb. 11, is not well placed for observation early in the month, but as the planet sets on Feb. 28 about $1 \frac{1}{4}$ hour after the sun, it can be seen in the western sky towards the end of the month. Venus is in superior. conjunction with the sun on Feb. I, and is not very well placed for observation during the month except towards the end, when it sets about 25 minutes after the sun and can be seen in the western sky. Mars, in the constellation of Gemini, is visible throughout the greater portion of the night and does not set before $6 \mathrm{~h}$. in the middle of the month. On Feb. 22 Mars is stationary. Jupiter, in the constellation of Virgo, cannot be seen before midnight early in the month, but is more favourably placed for observation later : the times of rising at the beginning, middle and end of the month are 23h. 47m., 22h. 56m., and 22h. respectively. The planet is stationary on Feb. 11. Saturn can be easily identified as it is a little south of Mars and can be observed throughout most of the night.

\section{Announcements}

Dr. S. WhItehead has been appointed director of the British Electrical and Allied Industries Research Association, of which he has been acting director since 1944.

Mr. J. BELl has been appointed chief research engineer of Messrs. Muirhead and Co., Ltd., as from March 1. Mr. Bell, who has been chief of the electrical group at the Admiralty Gunnery Establishment, has been associated with many developments, including remote indication and transmission units (magslips); also servos, electrical computing mechanisms and ship stabilization. Mr. Bell was educated at Arm. strong College, University of Durham, and received some of his practical experience in shipyards on the Tyne and also at Messrs. C. A. Parsons.

The 1946 Conference of the X-ray Analysis Group of the Institute of Physics will be held at the Royal Institution, London, during July 9-11. It is hoped that several distinguished foreign men of science will participate in the proceedings. Further information will shortly be available from the honorary secretary, Mr.F.A. Bannister, Department of Mineralogy, British Museum (Natural History), Cromwell Road, S.W.7. 